\title{
Glaciation and Periglacial Morphology in the Northwestern Venezuelan Andes
}

\author{
Dedicated to the memory of Carl Troll
}

\author{
by Carlos Schubert, Caracas
}

With 5 figures and 2 plates

\begin{abstract}
A bst ract. Evidences of previous glaciation in the northwestern Venezuelan Andes, mainly in Páramo de Piedras Blancas, include a main morainic level at 3400 to $3700 \mathrm{~m}$, and minor moraines at higher elevations up to about 4300 . Glaciated valleys, hanging valleys, rock, steps, glacial channels, cirques, arêtes, horns, striae and grooves on polished rock, roche mountonnés, and whaleback forms, are the main evidence of glacial sculpture and erosion. The main morainic level probably represents a Late Wisconsin glacial advance, and the higher moraines are either neoglacial or due to minor readvances during the main postglacial retreat. The main morainic level, $400 \mathrm{~m}$ higher than that in the southeastern Venezuelan Andes, indicates that the glacial climate was drier in the northwestern part than in the southeastern part of this mountain range.

Present-day periglacial features include micro-terrassettes, turf exfoliation, talus, and striated ground, above $3500 \mathrm{~m}$; and nonsorted stripes, sorted polygons or sorted circles, and sorted nets, above $4000 \mathrm{~m}$. The present-day periglacial zone is located between approximately 3600 and $4700 \mathrm{~m}$. During glacial times it probably reached down to $2400 \mathrm{~m}$ in the southeastern, and $2900 \mathrm{~m}$ in the northwestern parts of the Venezuelan Andes.
\end{abstract}

$\mathrm{Z}$ us a m m e $\mathrm{n}$ a s s u $\mathrm{ng}$. Zu den wichtigsten Zeugen einer früheren Vergletscherung in den nordwestlichen venezolanischen Anden, hauptsächlich im Páramo de Piedras Blancas, zählen ein Hauptmoränenniveau ( 3400 bis $3700 \mathrm{~m}$ ) und höhere Moränen bis zu $4300 \mathrm{~m}$. Trog- und Hängetäler, Felsstufen, glaziale Schmelzwasserrinnen, Kare, schroffe Grate, Horne, Gletscherschrammen und -furchen auf poliertem Gestein sowie Rundhöcker und Walrücken sind die wichtigsten Zeugen der Glazialskulptur und -erosion. Das Hauptmoränenniveau wurde wahrscheinlich durch einen Jungwisconsin-Gletschervorstoß gebildet, und die höheren Moränen sind entweder neoglazial oder sie wurden durch kleine Vorstöße während des postglazialen Hauptgletscherrückgangs gebildet. Das Hauptmoränenniveau, das $400 \mathrm{~m}$ höher liegt als in den südöstlichen venezolanischen Anden, deutet darauf hin, daß das Glazialklima im nordwestlichen Teil dieser Kordillere trockener war als im südöstlichen Teil.

Die heutigen Periglazialformationen enthalten: Hänge mit Bodenfließmarken, Rasenstufen, Schutthalden und Felsenmeere sowie Streifenböden über $3500 \mathrm{~m}$; nicht-sortierte Streifen, sortierte Polygone oder sortierte Zirkel; über $4000 \mathrm{~m}$ sortierte Netze. Die heutige Periglazialzone liegt ungefähr zwischen 3600 und $4700 \mathrm{~m}$ Höhe. In der Eiszeit hat ihre untere Grenze wahrscheinlich bis $2400 \mathrm{~m}$ im südöstlichen Teil, und bis $2900 \mathrm{~m}$ im nordwestlichen Veil der venezolanischen Anden gereicht.

\section{Introduction}

The Páramo de Piedras Blancas, the most extensive high altitude zone in the northwestern Venezuelan Andes (Sierra de La Culata), is located (Fig. 1) between approximately $8^{\circ} 50^{\prime}$ and $8^{\circ} 54^{\prime} \mathrm{N}$. latitude, $70^{\circ} 51^{\prime}$ and $70^{\circ} 55^{\prime} \mathrm{W}$. longitude. It lies between the upper reaches of Río Chama, which is Quebrada (=creek) Mifafí, and Quebrada Piedras Blancas (Fig. 2). The Río Chama flows longitudinally along the central, fault-controlled, valley of the Venezuelan Andes, in a southwest direction, and the latter flows directly northwest, both ending in the Lake Maracaibo Basin. The area of study lies between approxi- 
mately 3700 and $4600 \mathrm{~m}$ elevation above sea level, in the pá r a m o zone, the wet, treeless, high altitude, alpine zone of the northern Andes (Ecuador, Colombia, and Venezuela).

The pre-Quaternary geology of the area has been studied by Kovisars $(1969,1971)$. It is underlain by a Precambrian (?) metasedimentary terrain (Sierra Nevada Formation), consisting of schist, gneiss, and amphibolite (metamorphosed to the amphibolite facies of regional metamorphism). These rocks are overlain by lower grade (greenschist facies) Upper Paleozoic (?) metasediments (El Aguila Formation), consisting of a sequence (bottom to top) of quarzite, phyllite and siltstone, and limestone. These rocks were intruded during the Triassic by the El Carmen Granodiorite and later smaller bodies of pegmatite. Structurally, the metasedimentary units crop out in broad, northeast trending, antiforms and synforms. Several northeast trending faults occur in the region, but the main structural feature is the Boconó Fault, a major geotectonic break which follows the valleys of the Río Chama and Río Santo Domingo, just southeast of the area (Kovisars 1971, Fig. 5). Postglacial right-lateral strike-slip movement has been inferred along this fault from displaced glacial and fluvio-glacial features (Schubert \& Sifontes, 1970, 1972; GiegengaCK \& GRAUCH, 1972a, 1972b). A northwestward thrust (Gavilán Fault) has been mapped by Kovisars (1971) along the upper Río Chama valley, west of the Boconó Fault trace.

Wilhelm SiEvers (1885-1886, p. 101-103), one of the first to describe glacial features in the Venezuelan Andes, visited the southern boundary of the Páramo de Piedras Blancas area, when he climbed the Pico Pan de Azúcar $(4620 \mathrm{~m})$, the highest peak of the

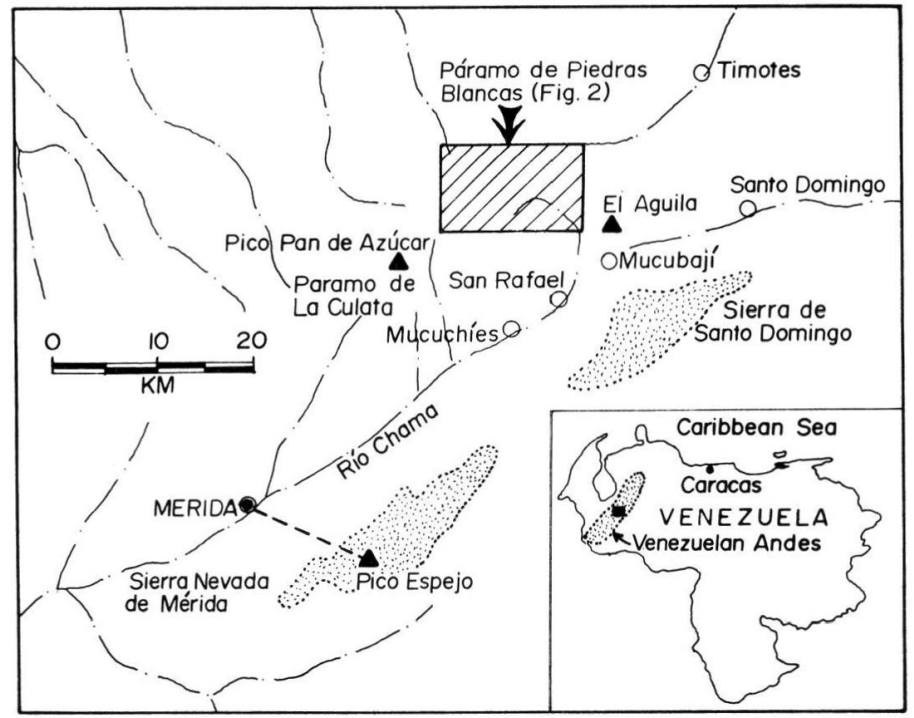

Fig. 1. Index map.

Páramo de La Culata region, north of the city of Mérida and just south of the study area (Fig. 1). However, he did not travel over the Mérida-Mucuchíes-Torondoy trail, which traverses Páramo de Piedras Blancas, along Quebrada Piedras Blancas. More recently, Royo y Gómez (1959) described briefly the moraines at the bottom of the Quebrada Mifafí valley (Fig. 2) and glacial features downvalley, along the Río Chama, to Mucuchíes. The glacial morphology of the Quebrada Mifafí valley was described by CÁRDENAS (1962), who mentioned the existence of U-shaped glacial valleys, arêtes, cirques, horns, 


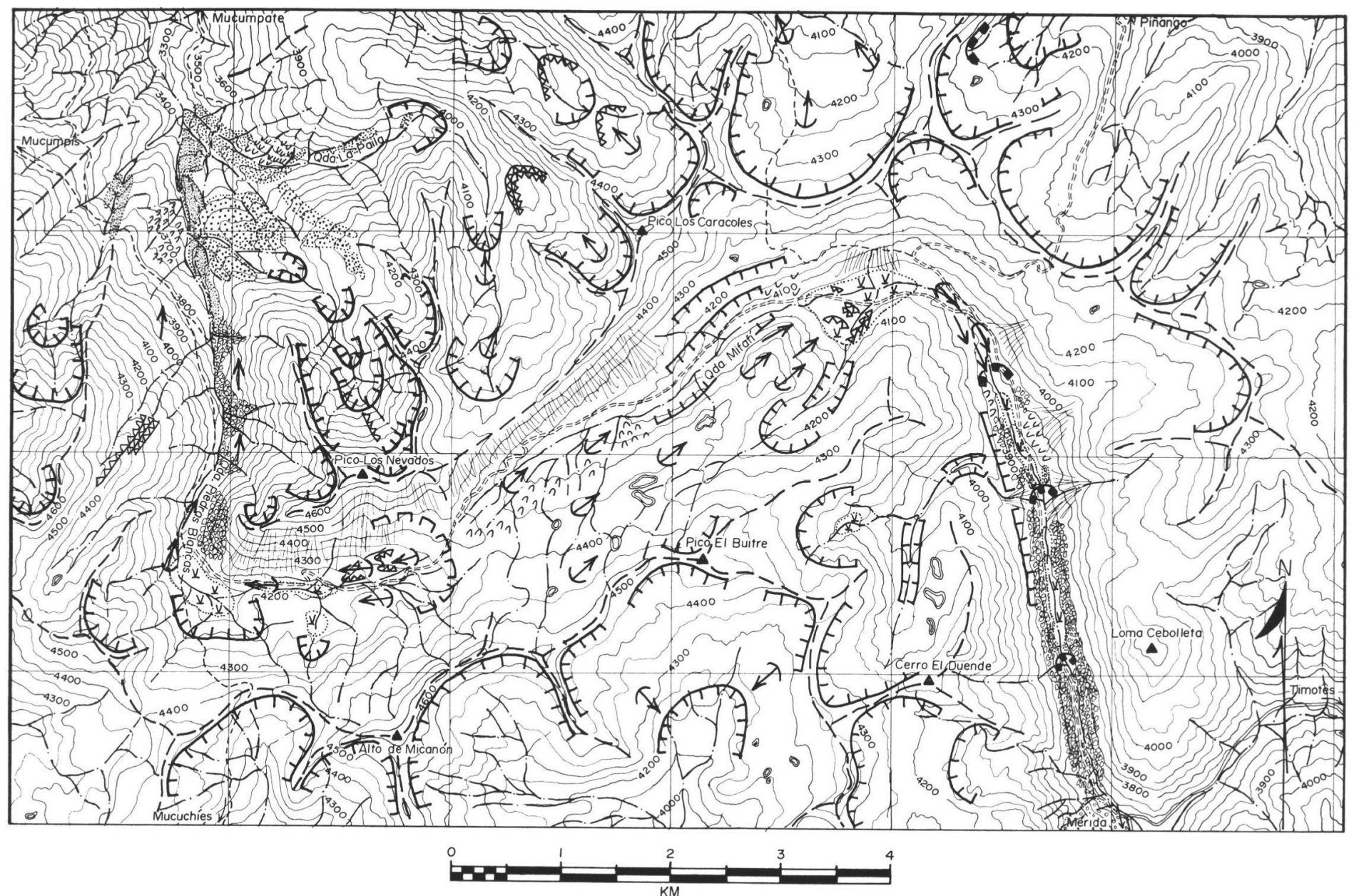

Fig. 2. Glacial geomorphologic map of Páramo de Piedras Blancas, Venezuelan Andes. Geology: C. Schubert. Base map: Cartografia Nacional (Caracas). No. 6042-III-NE; 6042-IV-SE, and $-\mathrm{NO}, 1974$. 


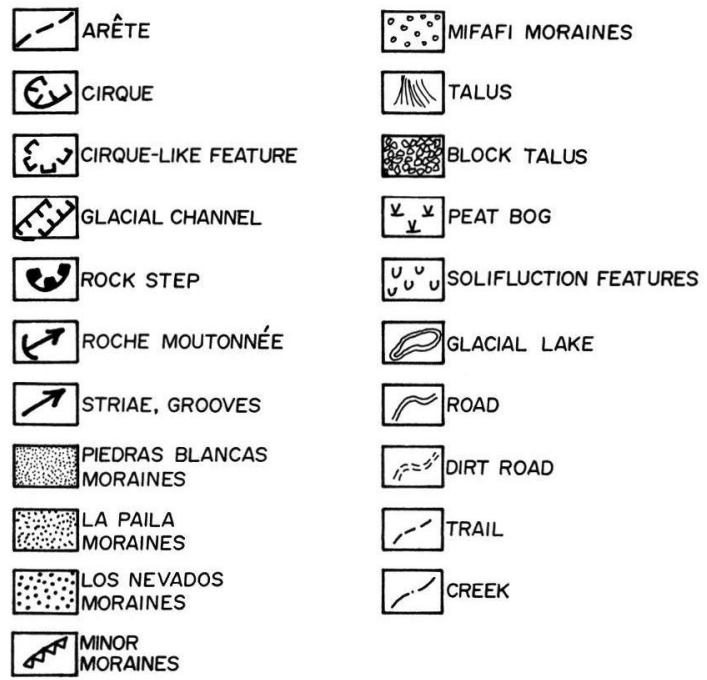

Explanations on figure 2.

rock, steps, striated and polished roches moutonnées, talus, flat valley bottoms probably representing ancient glacial lakes closed by morainic deposits, and remnants of lateral moraines along the right side of the valley. Kovisars (1969, p. 100-103) briefly described the glacial features of the Páramo de Piedras Blancas area. This author mentioned the existence of terminal moraines in the Quebrada Piedras Blancas valley (Fig. 2 and Plate I a), described in more detail in the present report.

The area of study is wholly within the páramo zone of the Andes, whose physical and botanical characteristics were treated in detail by Azócar (1974), is characterized in general by high humidity and a great daily range in temperatures (up to a daily freezethaw cycle). Table 1 lists typical rainfall data of stations close to the area. From these data, and the distribution of the stations (Fig. 1), it is clear that the southeastern part of Páramo de Piedras Blancas is in a "dry" belt (yearly rainfall between 600 and $800 \mathrm{~m}$ ) lying along the central axis of the Venezuelan Andes (this would correspond to the Subalpine Páramo, a climatic definition by EwEL \& MADríz 1968, p. 223). Both to the northwest and the southeast, yearly rainfall increases considerably in a short distance, to over $1200 \mathrm{~mm}$ in Santo Domingo (the climatic Pluvial Páramo of Ewel \& Madríz 1968, p.

Table 1

Rainfall data (monthly average in $\mathrm{mm}$ ) for selected stations near the Páramo de Piedras Blancas area (After Ministerio de Obras Públicas, Dirección de Obras Hidráulicas, Caracas).

\begin{tabular}{|c|c|c|c|c|c|c|c|c|c|c|c|c|c|}
\hline & J & $\mathrm{F}$ & $M$ & A & $M$ & J & J & A & $S$ & O & $N$ & D & Year \\
\hline $\begin{array}{l}\text { Páramo de la Culata } \\
(3000 \mathrm{~m} ; 1961-1970)\end{array}$ & 35.7 & 22.5 & 44.5 & 180.3 & 162.2 & 101.5 & 75.3 & 109.3 & 118.0 & 173.4 & 129.0 & 34.7 & 1186.8 \\
\hline $\begin{array}{l}\text { Mucubaji } \\
(3550 \mathrm{~m} ; 1969-1973)\end{array}$ & 29.6 & 17.9 & 25.1 & 118.4 & 95.1 & 130.3 & 128.9 & 121.0 & 133.8 & 103.2 & 66.0 & 21.8 & 991.1 \\
\hline $\begin{array}{l}\text { Pico El Aguila } \\
(4090 \mathrm{~m} ; 1953-1970)\end{array}$ & 8.6 & 7.8 & 17.4 & 68.1 & 103.4 & 124.4 & 127.7 & 97.9 & 83.4 & 86.5 & 54.6 & 16.3 & 796.1 \\
\hline $\begin{array}{l}\text { Páramo de Mucuchies } \\
(3750 \mathrm{~m} ; 1942-1970)\end{array}$ & 8.5 & 8.6 & 17.9 & 69.9 & 107.2 & 130.6 & 143.4 & 109.7 & 80.5 & 80.3 & 38.9 & 18.2 & 813.7 \\
\hline $\begin{array}{l}\text { San Rafael de Mucuchíes } \\
(3200 \mathrm{~m} ; 1949-1970)\end{array}$ & 6.5 & 4.3 & 13.4 & 66.7 & 92.0 & 80.2 & 91.1 & 77.5 & 77.7 & 71.9 & 31.6 & 8.5 & 630.4 \\
\hline
\end{tabular}


223-229). These climatic conditions are the result of the geographical location and orientation of the Venezuelan Andes. WALter (1973, p. 123-130) summarized the climatic conditions of Venezuela. During the winter months (northern hemisphere: November to April) the main part of Venezuela is unter the influence of the northeast Trade Winds which, over land, change to a more easterly direction over the Llanos (east of the Andes), and a more northerly direction in the Maracaibo Basin (northwest of the Andes). As these winds reach the Andes and ascend, the scant moisture left in them after discharge when reaching the Caribbean Sea, is dropped in the foothills and flanks of the mountain range. Little moisture reaches the internal valleys of the Andes (such as the Río Chama valley). During the summer months (May to October), the main part of Venezuela is under the influence of the Inter-Tropical Convergence Zone, and therefore receives abundant rain. A climatic profile across the Venezuelan Andes, illustrating these climatic conditions, was published by FLOHN (1968). The vegetation of the páramo zone has been recently described in detail by VARESCHI (1970); outstanding are several species of Espeletia.

This study of glacial evidence in Páramo de Piedras Blancas is the first in the northwestern Venezuelan Andes (Maracaibo Basin side). Up to now, earlier publications on glaciation (T'ricart 1966; Schubert 1970, 1972a, 1972b; Schubert \& Valastro 1974) dealt with the central and southeastern parts (Sierra de Santo Domingo, Mucuchíes area, Sierra Nevada de Mérida, and Páramo de La Culata). A comparison between these areas and Páramo de Piedras Blancas is of interest, because there are indications of climatic differences during glacial times between the southeastern, central, and northwestern Venezuelan Andes, just as there are differences at present (humid in the southeastern and central, and relatively dry in the northwestern Venezuelan Andes). Finally, periglacial features are described in a effort to define more precisely the contemporary periglacial zone in the Venezuelan Andes.

Aerial photographs were essential in mapping the distribution of the glacial and periglacial features, especially Photographs No. 140 to 149,214 to 226, and 533 to 536 of mission A-34 (CARtografía Nacional, Caracas). Elevations were determined with a Lambrecht altimeter, whose accuracy is at best within $20 \mathrm{~m}$. The altimeter was frequently checked during the day at points of known elevation.

\section{Glacial and fluvio-glacial deposits}

In the Quebrada Piedras Blancas valley (Fig. 2), between approximately 3400 and $3700 \mathrm{~m}$, there is an extensive complex of moraines forming a prominent level within the valley (Plate I a). Well-formed lateral moraines in the valleys of Quebradas Piedras Blancas and La Paila, are called in this paper the Piedras Blancas and La Paila Moraines. The latter is preserved best, including an end moraine which has been dissected by the stream. In the lower part of the Quebrada Los Nevados valley (below Pico Los Nevados), another morainic complex (Los Nevados Moraines) crops out: this one partly overrode the Piedras Blancas right lateral moraine (Fig. 2).

The lateral moraines, forming typical arcuate ridges, begin at the rocky outlets of the glaciated valleys (above 3600 to $3700 \mathrm{~m}$ ) and descend to $3400 \mathrm{~m}$, where they end either as an end moraine or as a gap cut by the stream flowing within the morainic valleys. The elevation of these morainic ridges ranges from 50 to more than $100 \mathrm{~m}$ above their central valley. Within the morainic valleys, the streams either have eroded away all the fluvioglacial deposits (Quebrada Piedras Blancas), or they are in process of eroding them (Quebrada La Paila), forming extensive, low terraces. Peat bog deposits, interlayered with fluvio-glacial sediments, are common in the valleys. 

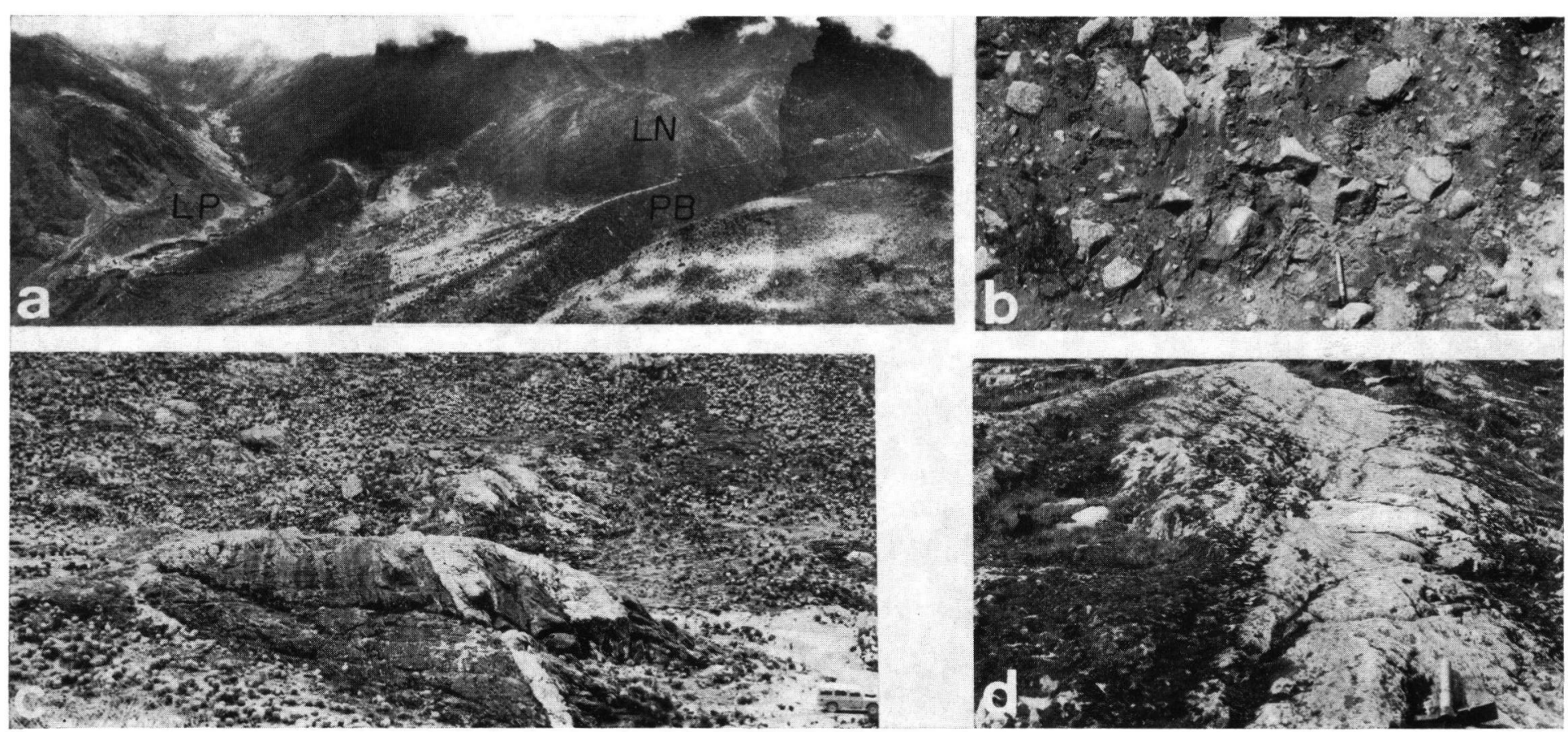

Plate I

a. Panoramic view of the main morainic level, Páramo de Piedras Blancas: $\mathrm{PB}=$ Piedras Blancas Moraines; LP $=$ La Paila Moraines; LN = Los Nevados Moraines. Note the fluvioglacial terraces within Quebrada La Paila velley. b. Typical till outcrop, Mifafí Moraines. c. Roche moutonnée, upper Quebrada Mifafí valley. Note the grooves on its side. d. Striated and grooved whaleback form in banded gneiss, upper Quebrada Piedras Blancas valley. 
In the area between the Piedras Blancas and La Paila Moraines (Fig. 2 and Plate I a), at least two remnants of older lateral moraines occur. These form low, straight ridges, not more than $20 \mathrm{~m}$ high, extensively covered by vegetation and talus deposits. They are parallel or subparallel to the Piedras Blancas lateral moraine, and could represent older glacial advances in that valley. This is supported by the fact that they were completely overridden by the Los Nevados Moraines.

Above the main morainic level, low $(10$ to $30 \mathrm{~m})$ minor moraines form arcuate ridges enclosing cirque outlets or rock steps. Several good examples occur in the Quebrada Mifafí valley (Fig. 2), where two small end moraines (mentioned by CÁrdenAS 1962) enclosed the lower two, elongated, flat bog areas, above the rock steps. These moraines (Mifafí Moraines) are partly covered by talus derived from the steep valley walls. At present, the stream has cut through these moraines and is actively cutting the rock steps. In the upper rock step, it has cut a small gorge with numerous examples of large potholes in the basement rock. In the upper bog area (called Llano Redondo), just above the place where Quebrada Mifafí turns upstream to the southwest, are three minor moraines (Fig. 2), which closed the outlet of the glacial channel just above them. They form low ridges which barely overlook the flat bog deposits. All of these minor moraines in the higher parts of Páramo de Piedris Blancas may represent either small glacial readvances during the main postglacial retreat of the glaciers, or they represent neoglacial moraines. The latter is probably the case for the moraines above $4000 \mathrm{~m}$, because of their relatively fresher appearance.

The moraines consist of till characterized by an unsorted and unbedded mixture of boulder- to clay-sized grains. Plate I a shows an outcrop of till from the Mifafí Moraine just west of Loma Cebolleta (Fig. 2). The fresh, dry till has a light gray (N 7 to $5 \mathrm{~B} 7 / 1$ in the Munsell Color System) color, and the main lithologic types among the pebbles and boulders are: granitic rocks, gneiss, mica schist, and minor amounts of amphibolite, pegmatite, and quartz. These rocks are typical of the underlying basement and also make up the high arêtes and peaks of the region, and they belong to the Sierra Nevada Formation (Kovisars 1971). The shape of the pebbles within the till is mostly prismoidal to ellypsoidal, usually fairly angular. Facets are well developed, and some striated pebbles were also found. These characteristics are similar to those described for tills and diamictons in other regions of the Venezuelan Andes (Schubert 1970; Schubert \& Valastro 1974), such as the northern flank of the Sierra de Santo Domingo and Páramo de La Culata (Fig. 1).

Fluvio-glacial deposits crop out mainly in the Quebrada La Paila valley (Fig. 2 and Plate I a), in the form of two main terraces, approximately at 3 and $10 \mathrm{~m}$ elevation above the creek level. The highest terrace (whose elevation ranges between 5 and $10 \mathrm{~m}$ ) ist best exposed in the lower part of the morainic valley, near the outlet through the end moraine, on the right bank of Quebrada La Paila. The sediment within this terrace consists of a sandy conglomerate with little apparent bedding. For this reason, it may also be a morainic deposit, possibly from a younger glacial advance, later modified by erosion. The sediment of the lower terrace (1 to $3 \mathrm{~m}$ elevation) consists of beds of varying thickness (a few centimeters to one meter or more) of conglomerates, conglomeratic sand, and sandy silt. In a few places, thin peat and carbonaceous layers occur within this terrace. Conglomeratic lenses, indicating former stream beds, are common within this terrace. The conglomerates contain pebbles of gneiss, mica schist, amphibolite, and granitic rocks (Sierra Nevada Formation and El Carmen Granodiorite; Kovisars 1971). Imbricate structures, together with the coarse-grained nature of these deposits, indicates torrential deposition. These sediments were deposited during and after deglaciation. Stratigraphically, the sediments of the upper terrace are older than those of the lower terrace. The main evidence for this is the fact that they only crop out along the lower inside edge of the La Paila 
Moraine and disappear upstream (either entirely or underneath the younger terrace deposits), and also because of its relatively greater weathering compared with the younger terrace sediments. The latter represent recent valley fill which is actively being cut at present by the stream.

A small outcrop of fluvio-glacial sediments occurs in the Quebrada Mifafí valley, just below the third rock step upstream. On the left bank, this deposit is about $6 \mathrm{~m}$ thick, and consists of thin $(5$ to $10 \mathrm{~cm}$ ) beds of conglomeratic sand and silt. The bedding is horizontal. This outcrop is covered by sandy conglomerate strongly influenced by solifluction, originated by the influence of the steep valley wall on which it lies and by the high water content which freezes and thaws frequently (probably daily). Solifluction has produced layers parallel to the slope but resting unconformably on the horizontal fluvial sediments. The latter contain fragments of granitic rocks, pegmatite, gray phyllite, amphibolite, gneiss, and quartz-mica schist. These rocks are typical of the Sierra Nevada and El Aguila Formations, which crop out in the eastern part of the Páramo de Piedras Blancas area (Kovisars 1971).

\section{Glacial sculpture and erosion}

Above the main morainic level (3400 to $3700 \mathrm{~m}$ ), the Páramo de Piedras Blancas region is characterized by the typical features produced by glacial sculpture. Among these, the most important are the glaciated valleys, hanging valleys, rock steps, glacial channels, cirques, arêtes, and horns. Fig. 3, a view of the upper Quebrada Mifafí valley, shows some of these features.

The main glaciated valleys are those of Quebrada Mifafí and Quebrada Piedras Blancas. These are typical U-shaped valleys, with very steep to vertical polished rock walls. In numerous places talus deposits (Fig. 2) produce a more gentle slope. In other

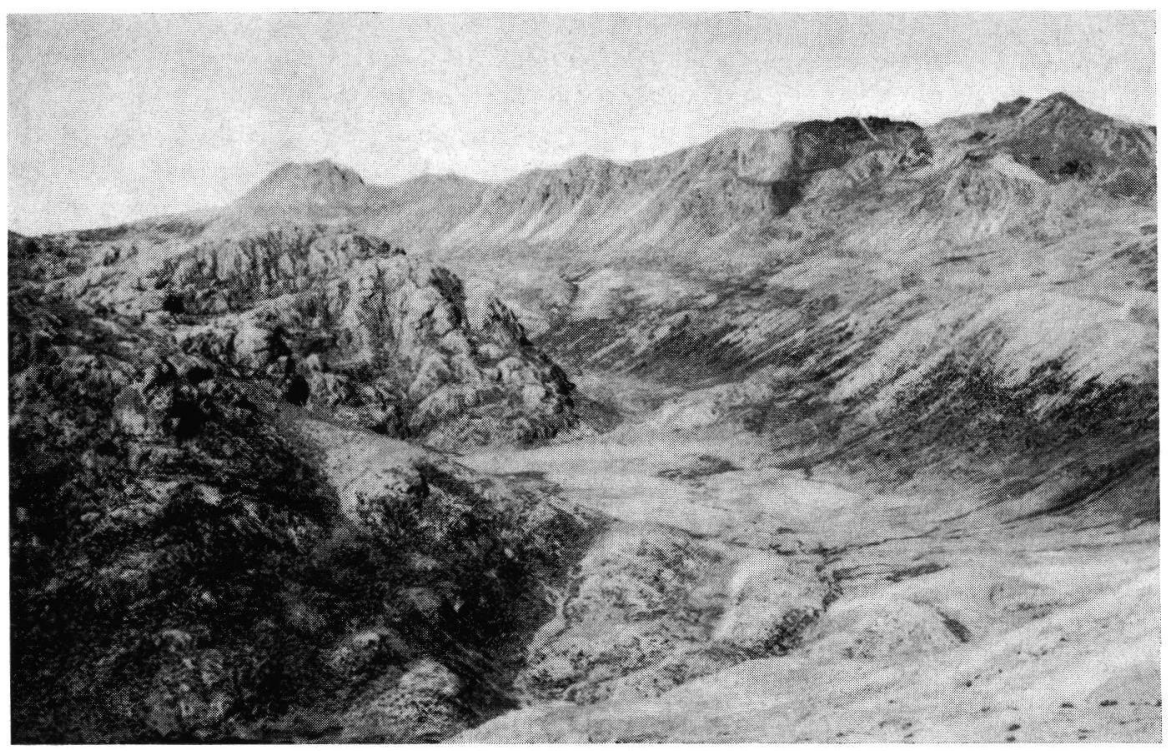

Fig. 3. Panoramic view of upper Quebrada Mifafí valley, to the southwest from road to Piñango. This view shows the glaciated valley, glacial channels, roche moutonnées, and the Llano Redondo bog area. 
places, bogs cover the bottoms of the valleys, and the streams are actively eroding. Hanging tributary valleys are common along the main glaciated valleys, ending usually in a vertical drop of 50 to $100 \mathrm{~m}$.

Rock steps are common features in the Quebrada Mifafí valley. A sequence of three well formed steps in the straight (southeast oriented) lower part of the valley, permit a flat bog area on the upstream side of each. These steps have a height of $20 \mathrm{~m}$ or more; higher steps in the upper part of Quebrada La Paila and Los Nevados may be more than $100 \mathrm{~m}$ high. In the latter case, the steps represent cirque outles. Glacial channels, long and usually straight troughs, are common in the Quebrada Mifafí valley, where they mark the upper erosional limit of the glaciers that filled the valley. From their height, it is inferred that the glaciers may have been $100 \mathrm{~m}$ or more thick.

Cirques are ubiquitous above $4000 \mathrm{~m}$ elevation. They are circular, bowl-shaped structures, with steep to vertical walls surrounding them laterally and upstream, and with an abrupt rock step downstream. The cirque bottoms often contain glacial lakes, and some cirques are closed by small moraines which were formed at the time when only cirque glaciers remained in the region. In other areas, such as the Sierra de Santo Domingo, Sierra Nevada de Mérida, and Páramo de La Culata (Schubert 1970, 1972a; Schubert \& Valastro 1974), the lowest cirques have bottoms at approximately $3500 \mathrm{~m}$ elevation. In Páramo de Piedras Blancas, however, the lowest cirque bottom is just below $4000 \mathrm{~m}$. The possible significance of this difference in terms of Late Pleistocene snow lines will be dealt with in the following section.

Above the cirques, at elevations over $4400 \mathrm{~m}$ and up to the highest peaks, the main geomorphological features are the arêtes and horns. The arêtes are narrow, rough, and very precipitous ridges which join behind the cirques, forming three-to four-cornered horns (GERBER 1969). The higher parts of these features were above the glaciers since no evidence for glacial action is found on them.

Glacial erosional features are widespread in the Páramo de Piedras Blancas region. The main ones are: striae, grooves, roches moutonnées, and whaleback forms. All of these are found in the upper parts of the glaciated valleys, above the limit of glacial and fluvioglacial sedimentation. Plate I d shows a whaleback form developed in banded gneiss (upper Quebrada Piedras Blancas), with prominent grooves and striae pointing in a downvalley direction. Plate I c shows an example of a striated and grooved roche moutonnée in the Quebrada Mifafí valley. The distribution of these features is shown in Fig. 2. Their orientation is clearly consistent with a downvalley glacier movement.

\section{Extent and age of glaciation}

From the glacial features described above and their distribution (Fig. 2), it is clear that the Páramo de Piedras Blancas region was formerly glaciated down to at least $3400 \mathrm{~m}$ elevation. This is the minimum elevation of end moraines in the region, and represents the minimum recognizable extent of the glaciers. In the Sierra de Santo Domingo (Schubert 1972b, 1973a) and Páramo de La Culata (Schubert \& Valastro 1974), a lower limit of possible moraines was described at 2600 to $2700 \mathrm{~m}$ elevation. Moraines were not found at this level in the Páramo de Piedras Blancas region, in the only area that reaches this low elevation, just off the map (Fig. 2) to the nortwest, near Mucumpate. The absence of this morainic level due to paleoclimatic drier conditions should not be dismissed without additional evidence. The higher elevation of the lowest cirque level in Páramo de Piedras Blancas, as compared with other regions to the southeast, mentioned in the previous section, may be explained by the existence of drier climatic conditions during glacial times in the central-northwestern part of the Venezuelan Andes. This 
would mean a Late Pleistocene snow line of just under $4000 \mathrm{~m}$, compared to approximately $3500 \mathrm{~m}$ in the Sierra de Santo Domingo and Páramo de La Culata. More certain paleoclimatic data require the results of recently begun palynological investigations, including the drilling of several peat bogs.

The age of the glacial features in the Venezuelan Andes was previously reviewed and discussed (Schubert 1972b and in press; Schubert \& VAlastro 1974). On the basis of radiocarbon dates and comparisons with similar features in the Sierra Nevada del Cocuy (Cordillera Oriental of Colombia, $500 \mathrm{~km}$ to the southwest and $4^{\circ}$ of latitude south of the central part of the Venezuelan Andes) (González et al. 1965), it was concluded that the main morainic level in the central and southeastern Venezuelan Andes (Sierra de Santo Domingo and Páramo de La Culata), at elevations between 3000 and $3500 \mathrm{~m}$, is probably of Late Wisconsin age (Late Glacial of GonzÁLEz et al. 1965). In the Colombian Cordillera Oriental this would correspond to the El Abra Stadial (VAN DER HAMmen 1974) which was correlated with the Younger Dryas time of Europe. Radiocarbon dating of peat layers within postglacial fluvial deposits in morainic valleys (ScHuberT 1970, Table 3; Schubert \& VAlastro 1974, Table 3) indicate a minimum age of approximately 10,000 years B. P. for these moraines. These radiocarbon analyses (IVIC-762 to -767 ; Tx-1436 to -1449) were done on sediments which were deposited after the glaciers had retreated at least from the lower part of the morainic valleys. Therefore, the age of the moraines themselves is significantly older than the radiocarbon dates reported so far. The lower morainic level (2600 to $2700 \mathrm{~m}$ ) was assigned to the main Wisconsin glacial advance (Pleniglacial of González et al. 1965). The term Mérida Glaciation has been proposed for the glacial event which produced the prominent till accumulation in the Venezuelan Andes (SCHUBERT 1974). An investigation on the radiocarbon chronology of the Mérida Glaciation was begun recently (in collaboration with the University of Texas Radiocarbon Laboratory), together with palynological analyses of peat and glacial lake sediments, in order to determine the Late Pleistocene and Holocene glacial and climatic evolution of the Venezuelan Andes.

The glacial features of the Páramo de Piedras Blancas region can easily be included within the Mérida Glaciation, because the morainic levels and sediments, described in previous sections, are identical to those described in other regions of the Venezuelan Andes. The main moranic level at 3400 to $3700 \mathrm{~m}$ is the equivalent of the main morainic level in the Sierra de Santo Domingo, Sierra Nevada de Mérida, and Páramo de La Culata. In these regions, this morainic level occurs at elevations between 3000 and $3500 \mathrm{~m}$. The difference in the lower limit between these regions and Páramo de Piedras Blancas (about $400 \mathrm{~m}$ ), supports the statement made above, that the snows line in the latter region during the last glacial advance was higher, possibly due to a drier climate (somewhat similar to the present-day climatic difference between Páramo de Piedras Blancas and surrounding regions, as shown in Table 1).

The minor moraines in the higher parts of the Páramo de Piedras Blancas region (above $4000 \mathrm{~m}$ ) are similar to those in the Sierra Nevada de Mérida (Schubert 1972a) and Páramo de La Culata (Schubert \& VAlastro 1974). They probably represent periods of minor readvances during the main postglacial retreat of the glaciers, or they may be neoglacial moraines. The last possibility has to be investigated in more detail, especially in terms of finding material suitable for radiometric dating.

\section{Periglacial morphology}

The term periglacial is used in the present report following WASHBURN (1973, p. 2), in that "it designates cold climate, primarily terrestrial, nonglacial processes and features regardless of date and proximity of glaciers". The Venezuelan Andes, between $7^{\circ}$ and 
$10^{\circ} \mathrm{N}$. latitude, clearly fall within TRICART's (1970, p. 26-27) periglacial climatic classification, as an area of mountain climates of low latitudes. These are characterized by extensive frost action due to frequent days of partial frost; no permafrost and only slight penetration of ground frost; and high humidity (except in arid regions) which aids soil movement.

In the Venezuelan Andes, climatic data of high altitudes are scant, consisting mainly of rainfall data (Table 1). Temperature records of sufficient duration have only been recorded at Mucubají, El Aguila, and the stations along the Mérida-Pico Espejo funicular (Fig. 1). Fig. 4 shows the average diurnal variation of the air temperature at these locali-

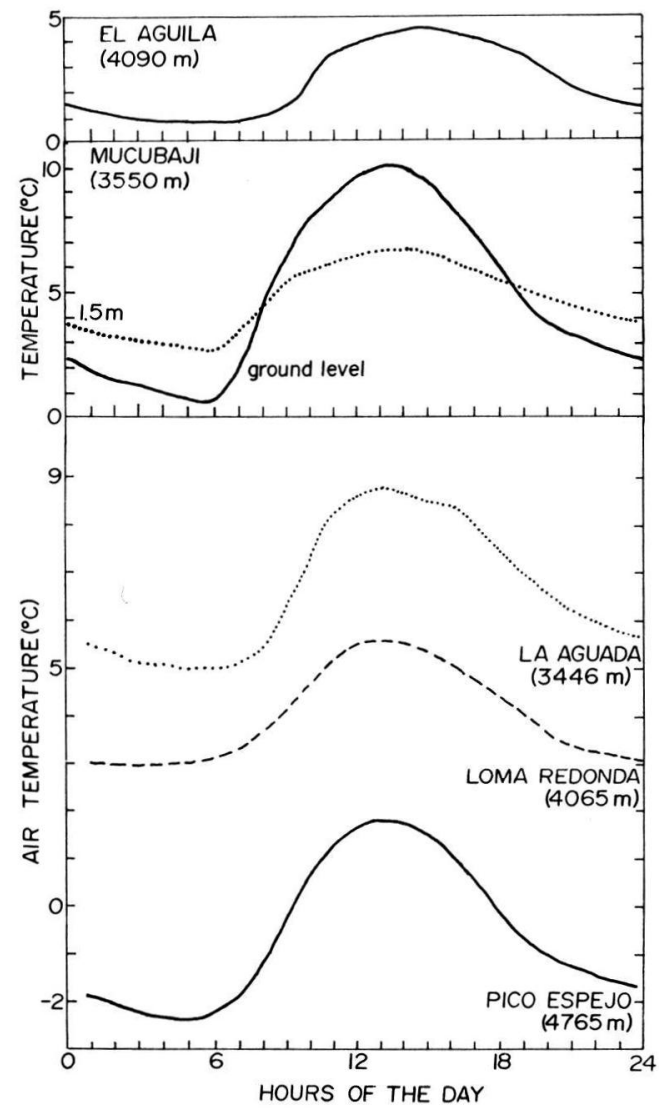

Fig. 4. Air temperatures at high altitude stations in the Venezuelan Andes (for location see Fig. 1). At El Aguila, the data was recorded between July and December, 1968 (Instituto De Geografía 1970, p. 37). At Mucubají, the data was recorded between April and September, 1968 (NiEto \& Arroyo 1968, Fig. 27). At the rest of the stations, along the Mérida-Pico Espejo funicular, the data was recorded during 1970-1971 (GonzÁLEz 1971, Figure 20).

Table 2

Temperature of soil at $30 \mathrm{~cm}$ depth, Venezuelan Andes (after Walter \& Medina 1969) Locality W. of Santo Domingo Mucubají Páramo de Mucuchíes El Aguila Pico Espejo

\begin{tabular}{lrrrrr}
\hline Elevation $(\mathrm{m})$ & 2915 & 3600 & 3940 & 4280 & 4765 \\
Temperature $\left({ }^{\circ} \mathrm{C}\right)$ & 9.6 & 5.0 & 3.9 & 2.0 & -1.5
\end{tabular}


ties. At Mucubají, in addition, the diurnal temperature variation at ground level is included. At Mucubají and El Aguila, the mean monthly minimum temperature reaches below freezing only during the months of December to March (NIETO \& Arroyo 1968, Fig. 30; Instituto DE Geografía 1970, p. 37). This means that Mucubají $(3550 \mathrm{~m})$ is below the limit of daily freezing and thawing. Fig. 4 shows that this limit is between 4065 and $4765 \mathrm{~m}$. Table 2 lists the scant soil temperature data (at $30 \mathrm{~cm}$ depth) for the Venezuelan Andes. From this it can be inferred that the permafrost region begins above approximately 4600 to $4700 \mathrm{~m}$, assuming that the soil temperature remains essentially constant below a few centimeters depth (WALter \& MEdina 1969). Furthermore, FahEY (1973) has recently shown that in the Colorado Front Range, the geomorphic effectiveness of freeze-thaw cycles is limited to the upper $10 \mathrm{~cm}$. From these climatic data, it can be tentatively concluded that the periglacial zone in the Venezuelan Andes is between approximately $3600 \mathrm{~m}$ and the lower limit of the glaciers (about $4700 \mathrm{~m}$ ), which are, at present, restricted to the higher parts of the Sierra Nevada de Mérida (Schubert 1972a).

In Páramo de Piedras Blancas, the lowest occurrence of needle-ice was observed at approximately $3600 \mathrm{~m}$. Lower occurrences are probable, because needle-ice is observed at Mucubají (3550 m), especially between December and March. However, the lower limit is not much lower than this, as freezing temperatures are usually not reached below $3500 \mathrm{~m}$ at any time during the year.

One of the most common periglacial features in the lower parts of Páramo de Piedras Blancas are micro-terrassettes (Fig. 5). These are formed by needle-ice solifluction on the steep valley sides, especially in the Quebrada Mifafí valley, where many slopes are covered by fine-grained talus and turf. In extreme cases, turf exfoliation is complete (Plate II a), formed by the process described by Troll (1973): needle-ice solifluction aided by deflation. Micro-terrassettes become less common above approximately $4200 \mathrm{~m}$, because of the rapid decline of the grass cover.

Block talus slopes are very common periglacial features also, and form extensive covers in both Quebrada Mifafí and Quebrada Piedras Blancas valleys (Fig. 2). Individual

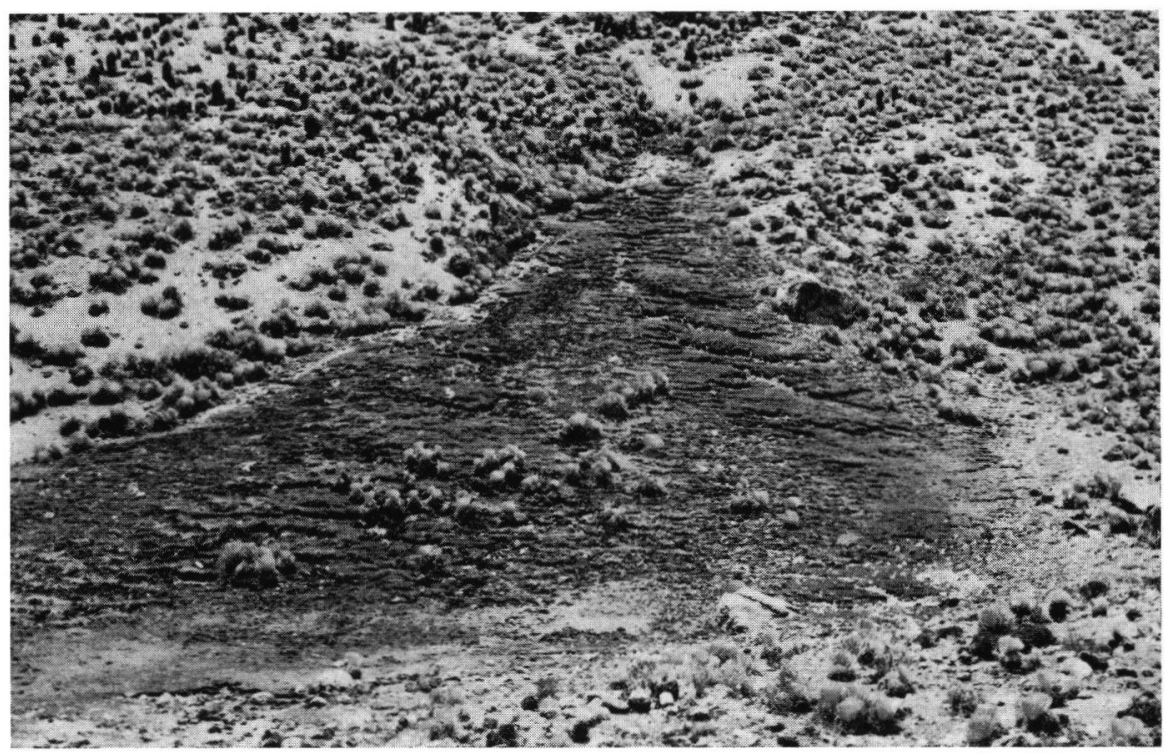

Fig. 5. Turf micro-terrassettes on solifluction lobe, upper Quebrada Mifafí valley. 
blocks range from cobble-size to several meters in diameter. They are derived from the high valley walls (arêtes and horns) by nightly freezing and ice-wedging of the rock. The process is very active at present, and breaking and falling blocks can be heard frequently during the night.

By far the most common periglacial phenomenon is the formation of striated ground (sorted stripes, according to WAsHburn 1956). This feature is practically ubiquitous above $4000 \mathrm{~m}$, although it is also commonly found down to approximately $3500 \mathrm{~m}$. The best examples are in the higher parts, because of the more frequent freezing and thawing cycles. Plate II b shows an example of striated ground. The striae are continuous for 10 to $20 \mathrm{~cm}$, and are separated by channels of 1 to $3 \mathrm{~cm}$ width and $1 \mathrm{~cm}$ depth. This feature was described previously in the Venezuelan Andes (Schubert 1973), and it was concluded that the orientation of the striae was essentially parallel to the prevailing wind direction, supporting Troll's (1944) observations. In the higher parts of the Quebrada Mifafí valley, needle-ice was observed every morning until about 10 or 11 hours (February and March), by which time it had melted completely. By the early afternoon, the striated ground was dry. There is clearly a gradation between the poorly-developed striated ground in the lower parts of the valley, and the well-formed striated ground in the higher parts. The latter can only form after several freeze-thaw cycles, because sorting proceeds slowly, becoming better with each progressive cycle (CORTE 1963).

Large nonsorted stripes are a less common feature in Páramo de Piedras Blancas (Plate II c). This feature is restricted to the highest parts, above $4200 \mathrm{~m}$, where the ground is barren and subject to daily freeze-thaw cycles. The ground material is sorted into sand and silt stripes, and pebble stripes. Plate II d shows a crossection of the stripes, which demonstrates that they are only a few centimeters deep. The sandy stripes are approximately 4 to $5 \mathrm{~cm}$ wide, while the pebble stripes ar 3 to $4 \mathrm{~cm}$ wide. This feature is very similar to that described by HastenRath (1971) in the Cordillera Real of Bolivia, and Hastenrath (1973), and Furrer \& Freund (1973) on Mounts Kenya and Kilimanjaro (East Africa). As in those regions, the pebble stripes are several centimeters higher than the sandy stripes. The grain size, however, can vary widely, as indicated by the occurrence of large nonsorted stripes in Páramo de Mucumposito (just northeast of the map area of Fig. 2), consisting of fine pebble stripes and stripes of coarse pebbles to cobble-size. Nonsorted stripes occur on moderate slopes, and they wind around boulders or rock outcrops, giving a raked appearance.

Incipient sorted polygons or sorted circles also occur in some of the flat areas, in the upper Quebrada Mifafí valley (above $4000 \mathrm{~m}$ ). These consist of roughly circular lines of pebbles and cobbles, surrounding areas of fine earth, usually covered by grass or made into linear features by needle-ice action (Plate II e). These are similar to those described by Washburn (1956). Associated with them also are incipient sorted nets of pebbles (Plate II f). These are restricted to shallow depressions in the high parts of the valley, where pebbles and cobbles apparently have collected through migration by freeze-thaw action from the surrounding slopes. In part, they are also similar to the stone packings described by Hastenrath (1971) in Bolivia.

Thus, the present-day periglacial zone of the Venezuelan Andes, characterized by most of the classical features of alpine periglacial zones, extends through approximately $1100 \mathrm{~m}$ vertical distance (from approximately 3600 to $4700 \mathrm{~m}$ ). The snow line during the Late Pleistocene Mérida Glaciation was estimated at $3500 \mathrm{~m}$ for the central and southeastern Venezuelan Andes (SchuberT, in press), and at about $4000 \mathrm{~m}$ in the northwestern part. In the first areas, this would correspond to a $1200 \mathrm{~m}$ drop with respect to the present-day snow line. In the northwestern Venezuelan Andes this would correspond to a present day snow line at approximately $5100 \mathrm{~m}$. Since no peak in this region reaches 

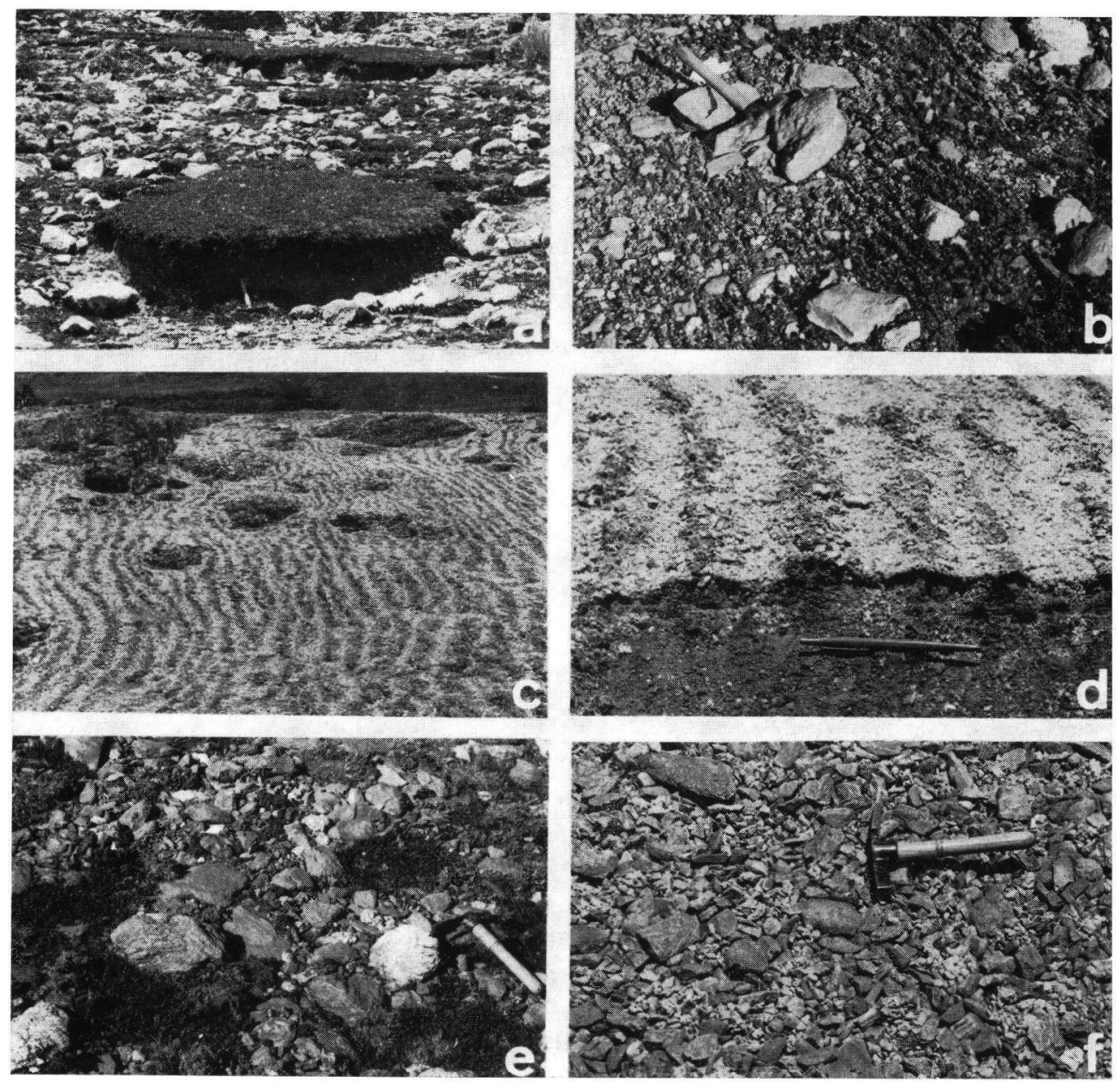

\section{Plate II}

a. Periglacial features, upper Quebrada Mifafí valley. a. Turf exfoliation. b. Striated ground. c. Nonsorted stripes. d. Close-up of section across nonsorted stripes of c. e. Incipient sorted polygons or sorted circles. f. Incipient sorted nets. 
such height, it is not possible to check this inference. Therefore, the periglacial zone during the maximum Late Pleistocene glacial advance (assuming a similar relationship between the glacial and periglacial zones as today) probably reached down to approximately $2400 \mathrm{~m}$ in the southeastern, and $2900 \mathrm{~m}$ in the northwestern Venezuelan Andes.

\section{Conclusions}

1. In the Páramo de Piedras Blancas region, northwestern Venezuelan Andes, evidence of previous glaciation include a main morainic level at 3400 to $3700 \mathrm{~m}$, with minor moraines at different levels above that; and evidence of glacial sculpture and erosion, such as glaciated valleys, hanging valleys, rock steps, glacial channels, cirques, arêtes, horns, striae, grooves, roche moutonnées, and whaleback forms. These are similar to those in other parts of the Venezuelan Andes, and belong to the Mérida Glaciation (Late Pleistocene), with higher moraines representing either minor readvances during the main postglacial glacier retreat, or they are neoglacial moraines. The main morainic and cirque bottom levels of Páramo de Piedras Blancas, are approximately $400 \mathrm{~m}$ higher than those of the Sierra de Santo Domingo, Sierra Nevada de Mérida, and Páramo de La Culata. This indicates a drier glacial climate in the northwestern part than in the southeastern part of the Venezuelan Andes.

2. Periglacial features in Páramo de Piedras Blancas include micro-terrassettes, turf exfoliation, talus, striated ground, nonsorted stripes, sorted polygons or sorted circles, and sorted nets. All of these are restricted to elevations above $4000 \mathrm{~m}$, except the first four, which also occur less perfectly developed down to $3500 \mathrm{~m}$, where freezing temperatures are reached only occasionally. Daily freezing and thawing is essential for the formation of the other features. The present-day periglacial zone in the Venezuelan Andes is between approximately 3600 and $4700 \mathrm{~m}$ elevation. During the maximum of the latest glacial advance (Mérida Glaciation), the lower limits of the periglacial zone were probably approximately $2400 \mathrm{~m}$ in the southeastern, and $2900 \mathrm{~m}$ in the northwestern parts of the Venezuelan Andes.

\section{Acknowledgements}

Robert GIEGENGACK reviewed and sagnificantly improved the manuscript; an earlier verson was reviewed by E. Medina, Z. BARUCh, and E. WAgner. I thank M. Monasterio, G. Sarmiento, and A. Azócar for introducing me to the botanical and climatic conditions of Páramo de Piedras Blancas, and for contributing many useful suggestion.

\section{References}

Azócar, A.: Análisis de las características de diferentes habitats en la Formación Páramo. - 73 p., Mérida, Facultad de Ciencias, Universidad de los Andes 1974.

Cárdenas, A. L.: El glaciarismo pleistoceno en las cabeceras del Chama. - Revista Geográfica 3, 173-194, Mérida 1962.

Corte, A. E.: Particle sorting by repeated freezing and thawing. - Science 142, 499-501, Washington 1963.

Ewel, J. J. \& Madriz, A.: Zonas de vida de Venezuela. - 264 p., Caracas, Ministerio de Agricultura y Cría 1968.

FAHEY, B. D.: An analysis of diurnal freeze-thaw and frost heave cycles in the Indian Peaks region of the Colorado Front Ranges. - Arctic and Alpine Research 5, 269-281, Boulder 1973.

Flohn, H.: Ein Klimaprofil durch die Sierra Nevada de Mérida (Venezuela). - Wetter u. Leben 20, $181-191,1968$.

Furrer, G. \& Freund, R.: Beobachtungen zum subnivalen Formenschatz am Kilimandjaro. Z. Geomorph. N. F., Suppl. Bd. 16, 180-203, Berlin u. Stuttgart 1973.

Gerber, E.: Bildung und Formen von Gratpipfeln und Felswänden in den Alpen. - Z. Geomorph. N. F., Suppl. Bd. 8, 94-118, Berlin u. Stuttgart 1969. 
Giegengack, R. \& Grauch, R. I.: Geomorphologic expression of the Boconó Fault, Venezuelan Andes, or geomorphology to a fault. - Geol. Soc. America Abstracts with Programs 4, 719-720, Boulder 1972 a.

- : Boconó Fault, Venezuelan Andes. - Science 175, 558-560, Washington 1972 b.

González, E. van der Hammen, T. \& Flint, R. F.: Quaternary glacial and vegetational sequence in Valle de Lagunillas, Sierra Nevada del Cocuy, Colombia. — Leidse Geol. Med. 32, 157182, Leiden 1965.

González, P. E.: Variaciones de los elementos climáticos a lo largo del corte Mérida-Pico Espejo. - 50 p., Mérida-Pico Espejo. - 50 p., Mérida, Trabajo Especial de Grado, Universidad de los Andes 1971.

Hastenrath, S.: Beobachtungen zur klima-morphologischen Höhenstufung del Cordillera Real (Bolivien). - Erdkunde 25, 102-108, Bonn 1971.

- : Observations on the periglacial morphology of Mts. Kenya and Kilimanjaro, East Africa. Z. Geomorph. N. F., Suppl. Bd. 16, 161-179, Berlin u. Stuttgart 1973.

Instituto de Geografía: Boletín climatológico. - 38 p., Mérida, Facultad de Ciencias Forestales, Universidad de los Andes 1970.

Kovisars, L.: Geology of the eastern flank of the La Culata massif, Venezuelan Andes. - 211 p., Philadelphia, Doctoral dissertation, University of Pennsylvania 1969.

- : Geology of a portion of the north-central Venezuelan Andes. - Geol. Soc. America Bull. 82, 3111-3138, Boulder 1971.

Nieto, J. A. \& Arroyo, J. M.: Introducción al clima del páramo en las cuencas altas del Chama, Motatán y Santo Domingo. - 59 p., Mérida, Trabajo Especial de Grado, Universidad de los Andes 1968.

Royo y Gómez, J.: El glaciarismo pleistoceno en Venezuela. - Asoc. Ven. Geol. Min. y Petróleo Bol. Inf. 2, 332-357, Caracas 1959.

Schubert, C.: Glaciation of the Sierra de Santo Domingo, Venezuelan Andes. - Quaternaria 13, 225-246, Roma 1970.

- : Geomorphology and glacier retreat in the Pico Bolivar area, Sierra Nevada de Mérida, Venezuela. - Z. Gletscherkde. u. Glazialgeol. 8, 189-202, Innsbruck 1972 a

- : Late Glacial chronology in the northeastern Venezuelan Andes. - 24th Inter. Geol. Cong. Report 12, 103-109, Montreal 1972 b.

- : Striated ground in the Venezuelan Andes. - Jour. of Glaciology 12, 461-468, Cambridge 1973.

- : Late Pleistocene Mérida Glaciation, Venezuelan Andes. - Boreas 3, 147-152, Oslo 1974.

Schubert, C. \& Sifontes, R. S.: Boconó Fault, Venezuelan Andes: evidence of postglacial movement. - Science 170, 66-69, Washington 1970.

— : Boconó Fault, Venezuelan Andes. - Science 175, 560-561, Washington 1972.

Schubert, C. \& Valastro, S.: Late Pleistocene glaciation of Paramo de La Culata, north-central Venezuelan Andes. - Geol. Rdsch. 63, 516-538, Stuttgart 1974.

Sievers, W.: Reiseberichte aus Venezuela. - Mitt. Geogr. Ges. Hamburg 12, 1-148, Hamburg $1885-1886$.

Tricart, J.: Geomorfología del área de Mucuchíes. - Revista Geográfica 7, 31-42, Mérida 1966.

— : Geomorphology of cold environments. - 320 p., London, Macmillan 1970.

Troll, C.: Strukturböden, Solifluktion und Frostklimate der Erde. — Geol. Rdsch. 34, 545-694, Stuttgart 1944.

- : Rasenabschälung (turf exfolation) als periglaziales Phänomen der subpolaren Zonen und der Hochgebirge. - Z. Geomorph. N. F., Suppl. Bd. 17, 1-32, Berlin 1973.

van Der Hammen, T.: The Pleistocene changes in vegetation and climate in tropical South America. - J. of Biogeogr. 1, 3-26, 1974.

Vareschi, V.: Flora de los páramos de Venezuela. - 425 p., Mérida, Ediciones del Rectorado, Universidad de los Andes 1970.

Walter, H.: Die Vegetation der Erde in öko-physiologischer Betrachtung (Band 1). - 743 p., Stuttgart 1973.

Walter, H. \& Medina, E.: La temperatura del suelo como factor determinante para la caracterización de los pisos subalpino y alpino en los Andes de Venezuela. - Boletín de la Sociedad Venezolana de Ciencias Naturales 28, 201-210, Caracas 1969.

Washburn, A. L.: Classification of patterned ground and review of suggested origins. - Geol. Soc. America Bull. 67, 823-866, Baltimore 1956.

— : Periglacial processes and environments. - 320 p., London, Erward Arnold 1973.

Manuscript received on 3. 12. 1974.

Address of author: Dr. C. Schubert, Centro de Ecología, Instituto Venezolano de Investigaciones Científicas, Apartado 1827, Caracas 101, Venezuela. 